\title{
LOOKING BEYOND THE SCIENCE CAPITAL: CONCEPTUALISATION OF 'SCIENCE FIELD' IN THE CONTEXT OF THE INDIAN SOCIETY
}

\author{
Ramjit Kumar a, and Smriti Singh b \\ ab Indian Institute of Technology Patna, Patna, India \\ Corresponding email: ramjithss@iitp.ac.in
}

\begin{abstract}
This paper explores beyond the concept of Science Capital originally proposed by Pierre Bourdieu and now advanced by a group of researchers lead by Archer et. Al, (2015) and claim that the concept of Science Capital continues to attenuate the fear of career and market related psychosis in young minds. Moreover, it doesn't give sufficient attention to processes of science related practices and behaviours in knowledge based society. Hence, to deal with the sociological variables a new theoretical construct called "Science Field" is innovated to measure the individual learner's ideas, and attainment of knowledge of, and about science, their habitus, scientific disposition and preferences, behaviours and practices related to science, and their aptness to apply scientific knowledge in their personal and social life. This theoretical lens and rubric is basically designed to measure and extrapolate the individual learner of what they possess science (Having Science) and how willing are they to practice science (Doing Science and Being Science), and also to explore nature of bond/affinity learners show with science (Science Recognition). It extends the opportunity to measure how much impact education and more particularly science education left on individual to decide over various sorts of things in real life situations. This is an important addition in sociology of science education literature to analyse the science education attainment from the perspective of scientific literacy approach to science education, and complement the Science Capital concept.
\end{abstract}

Keywords: Science Education, Nature of Science, Science Capital, Science Field.

"The way to do is to be."

-Lao Tse

"Darwin matters because evolution matters. Evolution matters because science matters. Science matters because it is the pre-eminent story of our age, an epic saga about who we are, where we came from, and where we are going."

Michael Shermer

"Social science should be interested in the problem of freedom and determinism as a matter of course."

\section{Introduction}

- Marshall Sahllin

In the book Reading America, Donoghue(1988) quotes Lionel Trilling whose central character, Mathew Arnold, in his book "The Scholar Gypsy" always keep in mind that all human values including human emotions are of social growth, if not social origin. According to Donoghue, (1988), Trilling's Mathew Arnold's preoccupations with society arise from the understanding that people can't live and act in a vacuum. Donoghue wonders whether air provided by society sustains or poisons the artististic imagination. Similarly, Foucault in his 
essay "What is Enlightenment" address Kant's quest of freedom of the human agency and its paramountcy over social structure. However, Varela,(2002) suggests any return to critical and humanist Kantian project of Foucault does not provide the adequate answer to the question that whether naturalistic world provide the ground to conception of the human agency. According to Varela, (2002), in spite of best efforts, Foucault wasn't able to make a successful bid to overcome the formulation domination of agency over structure that has set, he claimed, science against humanism, and human freedom in critical defiance of science. As a consequence, he suggests, we have been left with an open debate of the roles of science and human agency in the post-Baconian age that has propelled the new science and the new set of social relationship across the world. Even though Marx and Weber had warned long ago about negative spiral effects of increasing mechanisation and rationalisation of society on an individual, and, an early modernist, Simmel (2011) has drawn attention to the distanciation process in society due to increasing gaps among individuals, science has failed to reciprocate the socio-organismic system in post-second world war. Even founding social thinker of sociology Emile Durkheim, was of the view that society act as a major force in acting, constraining and conducting the individuals. It is in works of Giddens that the primacy of structural determinism over individual agency has taken a U-turn. Although Giddens took radical departure to overcome subject-object dualism to conceptualise the dialectical relation between the two, he posed structure as both medium and outcomes of human practices assuming that it constrains as well as facilitates the human capacity. Hence, he emphasises that social theory must acknowledge and express mutual dependence between structure and agency and reworks the associated concept and term to connect the human agency with structural analysis. This analysis of dynamism between individual agency and structure certainly negates (a). Neo-functionalist's conceptualisation of human as a cultural dope in society, (b). Structuralist formulation of determinism by Gurvitch and Sartre, and, (c). and also Parsonian formulation of System and Voluntarism. Hence, Giddens by expounding the structuration theory, he certainly reinvigorates Kantian's original formulation of embodied human agency versus deterministic social structure.

In the context of increasing roles and importance of science, scientism and scientification of society, the discussion of human freedom, individual as social agent and structural constraints have gained renewed attention in the wake of rapidly changing nature of knowledge and society. This paper makes an attempt in a direction within the domain of science education literature that explores whether there is any real constraint or threats to human freedom against deterministic structure? Or, a clearer question could be: how do we understand how human freedom and human autonomy works amidst the new social determinism that has sprouted all in society as Giddens has called in the formulation of structuration theory. This question has also gained wider acceptability in the light of "proactionary principle", put forwarded by first, Max Moore and later extended by Fuller, (2014), that aims to guide the progress of the idea that humans have innate capacity for selftranscendence and can be historically distinguished from other life creatures like ape. The remarkable motto of this principle of Proactionary Imperative is that humans are historically distinguished from other life creature that has innate capacity and possibility for transgressing one-self. It emphasises that human has the freedom to be whoever one wish. Such consideration compels us to ask the normative question that what does it mean to be, act, and exert own freedom in a responsible way in a world where humans are consistently striving to increase our power? More than human power and its agency, and possession of scientific knowledge, the adequate answer to this question lies in application of the knowledge into practice in private and public life on ethical dimensions (Stehr, 1986). This necessitates knowledge of humanities, ethics and personal integrity along with knowledge of science. We need appreciation and application of knowledge of human evolution, life, universe as well as evolution of moral ethics. As per Fuller (2004), since democracy has transcended its origin in classical Athens to embrace the scale and scope of human diversity across the world, human has to transcend its traditionally imposed ascripted identity to achieve its full potential and innate capacity to distinguish themselves from primates. 
Bachelard, (2002, p.28), in his book “The Formation of Scientific Mind", has cautioned us to take note of the fact that the evolution of scientific mind is an ongoing process. According to him, there is science only if schooling is permanent. Paraphrasing what he has the view of, the formation of training of scientific mind must be the part of continued culture (original emphasis), as the root of modern scientific civilisation. As, scientific revolution requires mental revolutions, Bacherlard, (2002, p. 25) suggests anything that does teach human being is bound to modify the person as a human being. In other words, at the heart of Bachelord's pedagogy is the praxis i.e. the ability to transform own self in the wake of new ideas, knowledge, and consciousness, what Bachelord has called 'intellectual modification'. In 1934, he had written another masterpiece called "The New Scientific Spirit" in which he says that since the mind works as conservative instinct, science calls a world in to being not through some magic force, immanent in reality, but rather through a rational force, immanent in mind. Here, Bachelard is fully convinced that problems of scientific mind must be found and understood in cognitive terms of sluggishness, stagnation and regression of the mind, what he has called epistemological obstacle/break that causes inertia to change rather than in inanimate, external obstacles.

Such consideration of how the mind stimulates, responds and brings dynamic changes in different socio-educational situations is, though, not a new subject matter of social scientists. In the wake of recent discussions and concerns of pedagogy of science teaching in school, it has attracted a new attention. The fundamental question, now, science educators are asking is: what entails the learning of science in terms of human development and civilizational processes. The point, science educators are emphasizing is that if science curriculum is not acting as transformative potential of the individual, how we can expect science education to rupture the ceiling of mind, acting as companion to open a new epistemological gateway. As a part of socio-historical transformation, science educators underlines that science education has definitive obligation to embrace the modern scientific outlook. In other words, science educators are at the helm of question that why not science education is at the centre of catalyst to spurring social changes in society that humanists are longing from so long. Fenshman (1984), in this regard, refutes any claim that science classroom rather than society should the centre of pedagogical activities and wonder that why not in the $21^{\text {st }}$ century science educator as a collective community are looking beyond the boundary walls of the classrooms to transpose the orders of society? According to him, science education lacks the social provinces in the curriculum and doesn't take into cognizance of the issues of the interface of science and society. Therefore, Fenshman concludes that it is more appropriate and inclusive vantage point to theorise the science education from a social point of view.

The theoretical base of such discussion of science in society is also grounded in many science-based movements like Peoples science movements in India, Public Understanding of Science in UK, Science for All in US, Nature of Science Teaching in many countries in PostSputnik era and Science and Technological Literacy as emphasised by many International agencies (OECD, 2005). Apart from this, increasing reach of globalisation as a phenomenon and process to farthest part of the country has increased the consequential impacts on various sectors of economy and enhanced the interdependency, awareness, and importance on people's mind. But, the stark inequality in population and uneven pattern in accessibility of education has adversely impacted overall performance in science education its impact on nation's growth and development, and, in current form is limited in breadth and depth of outreach. It has also skewed representation from the demand side of science education sector. The other important issue that touches the science education curriculum is the grim fact that uneven pattern in participation and performance in science education is worsening the situation (PISA, 2005). It has been a matter of great concern for national policy makers. Certainly, there is more need to be done, not only to expand the broad horizon of science education, but also to make science education more inclusive, cultural and participatory. It is noteworthy, here, that the unstated goal of science education in India has been to produce more number of scientists rather to produce learners to act as a scientist. 
Unfortunately, we are not recognizing the very fact that the smaller base of talent pool of learners is negatively affecting the availability of scientists contributing in the national growth and output. So, it is not only that worrisome performance of science education at international level is worrisome. This over-emphasis of quantity at the cost of quality in science education is tantamount to disserving the nation and society. Hence, to ensure the sufficient scientifically literate population from diverse population, what we first need to know is, as research by Smith et al, (2010) has suggested to removing the deep, but structured stumbling blocks in accessibility of science education that act as glass ceiling. Aikenhead, (2006), Haydock (2011) among others has pointed out that the other problems science education facing are learners don't feel intrinsically related to subject matter of the content, and in the end left the class feeling alienated, and disenchanted from the whole process of learning and educational activities. The rote-memorisation, crumbling process of teaching and mugging up concepts for examination etc. give the impression that learning science is not a part of self-growing process that acts as un-motivational, and external process of learning for personal development of learners. The fact that most science curricula does not has adequate provision to commensurate the personal epistemology with epistemology of knowing science also acts as a stumbling factor in learning science.

\section{Looking Beyond the Science Capital}

Michael, (2006) has argued that the possession of scientific knowledge and resources helps learners to translate into their increased social agency. Similarly, Claussen and Osborne, (2013) has argued that science qualification commands a strategic value in education and labour market. In 2012, Archer et. al. has shown that families with higher level of science capitalipromote their interest through in-family socialisation. They have shown that higher educational qualification of parent reciprocates the acquisition of science capital. Archer et. al. argue that the science capital is the quantum term that captures the overall knowledge of science related education and also what and how to do with that knowledge. Further, it acts as a card that students need for strategic purposes when they think suitable to use. They have formulated such claim by pointing to new educational variable called science capital. This is a brilliant sociologically crafted concept innovated by a group of researchers lead by Archer,(2005). They claim to capture 'the sum of total capital possessed by learner related with science and science related issues'. In this regard, this paper by critically appreciating the concept of science capital forward the claims that (a). it lacks the deep sociological nuances and vividness (b). base their reference from only narrowly conceptualised notion of learning of science i.e. possession of science that matter only for external examination criterion (c). it continues to creep the career, and market related psychosis among young minds. (d). oversimplify the transferability of science related capital from one generation to next generation. The paper, thus, sees it as a compelling case to make the point that this is the major problem with the update of Bourdieu's theory of cultural theory and theory of practice in the domain of sociology of education and attempts to make the convincing argument that there is the need of new analytical tool and conceptual schema that can (a) explore individual leaner's stock of knowledge-base of Nature of Science, (b). habitus and disposition related to science education (c). examine the nature (instrumental/organic) relationship with science (d). overall allegiance/affinity with science in their daily life.

The concept of science capital has undermined the place of individual as a self-reflexive agent in family, community and societal set-up. The underlying assumptions that follow is that what one has acquired as a member of family play determining roles in opting the science related careers and choices. This is crucial lapse in the estimation of individual learner's potential and innate capability to learn and act, knowing from various sources of information like print and digital media. In other words, the very premise of educational potential of the learner that is more than what one inherits from earlier generations is undermined in the conceptualisation of science capital. This personal, but significant autonomous and reflexive space is crucial in what learner strives to be and become. The concept of science capital elapses such point and prefers to rather look for socio-cultural differences. Scientific literacy approach to science education sees such an argument utterly 
uneducated and belies the progressive-liberal importance and values of education that it puts in the individual-self. Freire convinces us that investment of education changes individual behaviours and transforms the people for lifelong learning. In this way, learners act on the basis of new knowledge and conscious that they gained from learning, and, do use their scientific knowledge to negate the social determinism and acquire what $\mathrm{s} /$ he wants to become. Such an understanding has provided a way out to new theoretical construct to be called Science Field that captures the various dimensions of science education like knowledge of science, its methods and procedures, their disposition towards science and preferences, behaviours and practices of science, and their affinity or allegiance with science. In other words, the concept of science field is a term/rubric that offers the opportunity to capture knowing, doing and being dimension philosophical dimensions of learning of science more so, by using empirical methodology on Likert scale analysis (See Appendix- I).

\section{The Concept of Science Field}

The need to take in to account of wholesome aspect of science education has brought the concept of Science Filed in to birth. It can be construed as individual learner's total sum of possession of knowledge, ideas, behaviours, habitus and disposition and affinity to science related to socio-scientific issues. This is an important tool that attempts to capture the scientific awareness of science from the perspective of scientific literacy. It measures the different components of science education that emphasises the praxis part of science education and complex negotiation that goes over science related issues and decisions.

The concept of Science Field is an autonomous space conceptualised for individual learner who is a social agent, and learning, struggling and trying to navigate themselves in the Social Field in Bourdieun sense, in the journey of transformation of from being to becoming. It is a space open for both possibilities, as well as problems to individuals who positioned themselves to make a move in informed direction. Shaped by many social variables like parental qualification, concerns, family income, life opportunities, level of literacy and awareness in society, geographical location etc. learners are usually in tough situation. The concept of science field recognises such situation and points out that such individual's space is independent, as well as dependent space in complex society. Hence, the Science Field is a theoretical construct as well as multivariate conceptual rubric deigned to measure the different components of science education like knowledge of nature of science, scientific disposition, scientific preferences and behaviours, affinity with science etc.to inform that how strong or weak is learner's autonomy to act on what they believe in strongly specially in science related issues? Whether individual learner as a citizen prefers to bow down or outgrow and act responsibly in what they believe in is captured by science field. Since, the nature of strength of tie of individual with science depends on knowing as well as being of science and doing science, the concept of science field reflects the chromatic picture of (a). possession of scientific knowledge (Having Science), (b). the knowledge of scientific methodology, and processes (c). how scientific they are or want to be in life (Being Science) and (d). Do they prefer doing science i.e. do they follow scientific methodology, reasoning, and rationality. (e). how they affiliate with science how strong bond is with science that show that how much importance they give to science in their life and whether learners are willing to rise on occasion and stand up for scientific understanding in public?

\section{The essential components of Science Field can be analysed in the following components-}

\begin{tabular}{|l|l|}
\hline Understanding Nature of Science & \multirow{2}{*}{ Having Science } \\
\cline { 1 - 1 } Understanding Methods and Principles of Science & Being Science \\
\hline Scientific Disposition and Preferences & Doing Science \\
\hline Scientific Behaviours and Practices & Affinity with Science \\
\hline Science Recognition & \\
\hline
\end{tabular}


The concept of Science Field looks broader in concept and more encompassing than the concept of science capital. As different items of scientific literacy add together, it is a compliment to see the broader picture of how science education is doing at individual level, as well as societal level. An individual conception of base of knowledge of and about science is important to know from science teaching pedagogical points of view. The construct of science field fulfils such vacuum in science education literature.

\section{Having or Being Mode of the Learning}

To have or to be is an important question of our time. And, it is more relevant in the context of science education, and, especially its increasing significance in the contemporary relevance of science education in knowledge society. The assumption that once a student has memorised the theoretical materials has gained mastery over the concerned subject has become vieuxjeu in knowledge society. It has been questioned from many perspectives: democratic, social, cultural, and moral points of view. In recent decades, science educators have criticised the utilitarian approach to science education that has set the primacy of passing the examination to get to the next level of course over other democratic arguments. Such conceptualisation of learning science overshadows other important aspecst of science like science has tentative character. Science is a social enterprise that involves creativity and imaginative as much as aptitude in the whole process.

Unfortunately, our educational system recognises only the educational possession of product of science like scientific laws, hypothesis, formulas etc. neglecting the process aspect of science. Pupils are generally not encouraged, appreciated and examined on the basis of subscribing and internalising the scientific temper, scientific attitude, disposition, preferences, behaviours, and practicesin their life (Being science and doing science). But, philosophy of education rightly educates us that to be is the most important category of the process of learning. In fact, 'to have', as the natural category in education paradigm is a problematic concept. According to Fromn, (2016) to have is of recent origin. It has started with connection of development of private property in society. In fact, many languages have no words for to have.

In the book 'To Have or To Be', Fromn elucidates the differences between having mode of existence and Being mode of existence. According to him, in having mode of existence the relationship to the world is of possessing and owning. In having mode of learning process the content of knowledge does not become the part of the individual and their cognitive process. New information just adds up in the stocks of knowledge as additional item and act as mere alien subjects to learners. New information is as good as a stranger to individual owner of scientific knowledge and seldom talks to each other except in examinations. On the other hand, in being mode of learning, learners do not go in classroom as tabula rasa and not approach the process of learning as empty receptacles. Similarly, the concept of being is related to learning processes aspect of science. Simmel called it transformation of an individual from being to becoming. However, Buddhist philosophy of human realisation have no concept of any enduring permanent substance, this concept of being" is very solidly grounded in Buddhist school of thought. Constructivist theory of learning also approach the learning as an active, alive and dynamic process and affect the change and also get affected by it.

\section{Different Components of Science Field 5.1 Understanding the Nature of Science}

Recently, the nature of science has enjoyed renewed attention in science education circles as a primary component of scientific literacy (AAAS, 1989). Leadermen et. al. (1900) defines it as knowing the epistemology of science. The very premise on which science is based is important to know and understand how science woks. The teaching of Nature of Science has got increased attention also because of public science movements, and popularisation of science related activities and curiosity like the origin of life, species and universe in general public, but more particularly in school students. It captures what learners know of, and 
about science, about epistemology of science (Lederman, 2013), the whole conceptualisation of science (Allchin, 2011), real practices of scientists etc. Along with learner's comprehensive understanding of science, there is a need to follow learner'sattitude towards science (Osborne, 2003), their habitus, preferences, behaviours and also their affinity/allegiance with science.

\subsection{Understanding Methods and Principles of Science}

Knowing the content of science education without comprehending the methods and principles of science does not serve the purpose of science education curriculum goals. The success of science goes to methods and principles adopted in the scientific investigation and processes. Among the activities often identified as the characteristics of methods of science is systematic observation, experimentation, inductive and deductive reasoning (Stanford Encyclopedia of Philosophy). How these are carried out is a great matter of interest to distinguish science from non-science, like pseudo-science and also to make to develop a healthy reasoning.

\subsection{Scientific Disposition and Preferences}

Scientific disposition and preference is the inward manifestation of personal habitus of the individual. Bourdieu has famously called it 'Habitus'. It includes the inclination, attitude and ways of knowing of individual. Disposition is built-in quality of the individual, but develop as a result of years of incessant observation and formal and informal learning. Disposition is the key component of science education learning that shape the attitude and inclinations of the individual. To sum up, what scientific disposition and preferences an individual learner has shown the quality of what can be called of "Being a person of Science" or in short Being Science. Some of the examples to understand the concept of Being Science can be given as follows: whether learners are interested in knowing the underlying causes, meanings, and reasons behind the phenomenon and whether learners are inquisitive enough about science related issues.

\section{Scientific Behaviours and Practices}

This is ,again, the manifestation of realm of affect, taste and aversion of individual agent regarding science related issues. But, this is the outward manifestation of personal habitus of individual learners. Whether a learner is a key player in society interested in observing and submitting to scientific behaviours and follows the consequent practices is grew from scientific reasoning that can be captured by this sub-aspect of Science Field and can be called Doing Science. Some of the examples of Doing Science are-

$\circ$ Every day science engagements

- Valuing science related issues

$\circ$ Acting as a scientist in society

\section{Science Recognition}

Science recognition captures that how much freedom/flexibility individual learner enjoys being in public with science allegiance? The question that it further pursues is the connection and affinity with science. For example, whether a learner does enjoy (i) being with scientific community (ii). Standing for science in public (iii). Spending time in science related public outreach engagement (iv). participating in science fair, and workshops (v). Love busting anti-science myths in public. Whether such activities and engagement regarding science related issues that meant to excite learner to act scientifically is captured by this and remains a matter to see.

\section{Discussion}

There is consensus that in the last decades in the domain of science education reform in India the pace of reform of epistemological nature in science education has been slow that need to be collaborated and upgraded with collaboration of cross-national reforms in science education to develop the epistemic values and skills in students. International agencies like 
UNESCO, OECD has also emphasised the need to temper science education with practical skills and human values. Even though there is little clarity on what constitutes Science and Technological Literacy, it is the new catching phrase. Backed by UNICEF, the concept of STL has gained ground in science education literature and science educators are mulling over the modalities of tailoring in curricular objectives to usher in such changes in Indian context. In an Indian context, there have been some studies on the checking the knowledge base of nature of science (Roy, 2003). But, such studies have been scattered and isolated. The scale of such studies has been such that hardly any sort of generalisation can be found.

The aim of this conceptualisation has been to discuss the concept of Science Field in the domain of sociology of science education to draw the clear picture of relationship between individual learner's affinity with science and science learning. This is a jumbo term that scales (see the Appendix) a. Nature of Science understanding (b). understanding of the basic principles and methodologies of science (c). attitude towards science and science learning captured by terms like scientific disposition and preferences and scientific behaviours and practices. The central point of this paper makes it that there is strong need to retrieve science education from objectivist epistemology and conceptualise in the broader public epistemology framework in the spirit of what Gibbons(1994) has called Mode II mode of production. The consequent implication of this is to development of theory of praxis in consonance with the Bourdieu's seminal book, "outline of theory of practice". Such empirical validation would certainly complement any attempt to theorise science education from praxis point of view and narrow increasing gap between theory and practice in society.

\section{Conclusion}

The exponential expansion of Science roles in many areas of social life is beyond our expectation. In the domain of science education, the concept of Science Field explores the reflexivity of individual learner as a self-agency. This concept by going beyond the concept of science capital hypothesise that transferability of scientific disposition of mind from one generation to another generation is not contingent on parental qualification in science related program. The acquisition of science capital is a much more complex activity and it is not the direct deduction of classroom teaching of science education program. Hence, first it has to be recognised that science capital has internal contradiction itself and there is need to move beyond this theory. To put it succinctly, the autonomy of science education learner can't be compromised just because of what individual learner has acquired less from family and community. More than science education should also measure not only possession of knowledge of scientific knowledge but also how do learner put the knowledge of scientific concepts, theories and laws to understand natural phenomenon in daily life and apply such scientific understanding for practical purposes (called being Science and doing Science). Hence, the concept of science field entails that (a). knowing of, and about science is as important as knowing in science content and (b). learning using of science as important as possessing or carrying of science knowledge. The concept of Science Field withholds the autonomy of learner to provide scaffold 'to do the things they want to exercise in private, public and social realms'. Hence, it negates any analogy of Science Capital's that individual learner uses science education as card like a player use in strategic situation. Taking notes of Habermas(1985) understanding of individual's action that the Science Field corroborates the conception that learner is more than a mere strategic player. As an autonomous social agent, they are in different roles, so, they do act differently in different situation and do not always use strategic tactics. They act sometimes out of affinity, love, emotions, political motives or empathy. In other words, science education learners are assertive citizens who can either opt to act for instrumental purposes or organic purposes. Hence, the right analogy for learners of science education is like pen which they always feel like keeping in their pocket, and love to possess, use and apply. 


\section{References}

i. $\quad$ Aikenhead \& Glen, S., 2006. Science Education for Everyday Life: Evidence-based Practice. New York: Teachers College Press.

ii. $\quad$ Ajeet, R., n.d. Science Education and Nature of Science Proceedings of episteme 4 India. s.l.:s.n.

iii. Allchin, D., 2011. Evaluating knowledge of the nature of (whole) science.. Science Education, 95(3), pp. 518-542.

iv. American Association for the Advancement of Science, 1993. Benchmark of Scientific Literacy. New York: Oxford University Press..

v. American Association for the Advancement of Science, 1993. Benchmarks for science Literacy. New York: Oxford University Press.

vi. Archer, et al., 2012. Science Aspirations Capital, and Family Habitus How Families Shape Children's Engagement and Identification with science. American Educational Research Journal , 49(5), pp. 881-908.

vii. Archer, L., 2015. "Science capital": A conceptual, methodological, and empirical argument for extending bourdieusian notions of capital beyond the arts. Journal of Research in Science Teaching , 52(7), pp. 922-948.

viii. Bachelard, G., 2002. The Formation of the Scientific Mind Clinamen.. s.l.:s.n.

ix. Bourdieu, P., 1977. Outline of a theory of practice. Cambridge: Cambridge University Press..

x. Bourdieu, P., 1977. Outline of a Theory of Practice. Cambridge, UK: Cambridge University Press.

xi. Bourdieu, P., 1984. Distinction: A Social Critique of the Judgement of Taste. London: Routledge and Kegan Paul, Ltd.

xii. Bourdieu, P., 1990. The Logic of Practice. Cambridge: Polity Press.

xiii. Bourdieu, P., 2004. Science of Science and Reflexivity.. Cambridge : University of Chicago Press and Polity Press.

xiv. Donoghue, D., 1988. Reading America: Essays on American Literature. California: University of California Press.

xv. Fensham, P., 2004. Defining an Identity: The Evolution of Science Education as a Field of Research. Dordrecht: Springer Science \& Business Media..

xvi. Freire, P., 2014. Pedagogy of the Oppressed.. s.l.:Bloomsbury Publication..

xvii. Fromn, E., 2013. To have or to Be Bloomsburrry Academic. New York: s.n.

xviii. Fuller, S. \& Lipinska, V., 2014. The Proactionary Imperative: A Foundation for Transhumanism.. New York: s.n.

xix. Gibbons, M., 1994. The New Production of Knowledge: The Dynamics of Science and Research in Contemporary Societies.. Stockholm: Sage.

xx. Giddens, A., 2013. The Constitution of Society: Outline of the Theory of Structuration. s.l.:John Wiley \& Sons.

xxi. Habermas, J., 1985. The Theory of Communicative Action: Reason and the Rationalization of society. Boston: Beakon Press.

xxii. Haydock, K., 2011. Why do we have problems learning and teaching science?. Contemporary Education Dialogue, 8(2), pp. 257-262.

xxiii. Lederman, Lederman, N., Judith, S. \& Antink, A., 2013. Nature of Science and Scientific Inquiry as Contexts for the Learning of Science and Achievement of Scientific Literacy. International Journal of Education in Mathematics, Science and Technology, 1(3), pp. 138-147. 
xxiv. Lederman, N. \& Flick, L., 2007. Scientific Inquiry and Nature of Science: Implications for Teaching, Learning, and Teacher Education. Dordrecht: Springer Science \& Business Media.

xxv. Masih, A., 1995. Scientific Literacy: Paramount criterion for evaluation of school science curriculum. Volume 10, pp. 57-67.

xxvi. McCommas, W., 1998. The Nature of Science in Science Education, 53-70.. s.l.:Kluwer Academic Publishers.

xxvii. Norman, L., Abell, G. \& Sandra, K., 2014. Handbook of Research on Science Education. New York: Routledge.

xxviii. OECD, 2004. Scientific Literacy: Measuring student knowledge and skills. In: J. Gilbert, ed. The Routledge Falmer Reader in Science Education. London: Routledge Falmer, pp. 59-75.

xxix. Osborne, J., Simon, S. \& Collins, S., 2003. ttitudes towards science: A review of the literature and its implications. [Online] Available at: http://dx.doi.org/10.1080/0950069032000032199.

xxx. Simmel, G., 2011. On Individuality and Social Forms. Chicago: University of Chicago Press.

xxxi. Sood, J., 1978. Understanding of science among NSTS awardees, teachers and nonselected NSTS students. Indian Educational Review, pp. 132-142.

xxxii. Stehr, N., 1986. The Knowledge Society:The Growing Impact of Scientific Knowledge on Social relations. s.l.:Springer Books.

xxxiii. UNESCO, UNICEF, CSEC, Mukherjee, A; Vijaya, S., n.d. Science and technological literacy for all: Experiences in India. [Online]

Available at: http://doc.iiep.unesco.org/cgibin/wwwi32.exe/\%5Bin=epidoc1.in\%5D/?t2000=018413/(100)

xxxiv. Varela \& Charles, R., 2009. Science for Humanism: The Recovery of Human Agency. New York: Routledge.

\section{Appendix- A}


This Questionnaire seeks learner's understanding of different components of Science Field- a concept that consolidate the knowledge and view towards science and different components of science education. It consists of knowledge nature of science, methods and principles of science, Scientific Disposition and preferences in your daily life, scientificbehaviours and allegiance with science.

\section{Please read the statements and mark the right box that best reflects your opinion. You may adopt any of the following as indicated by numeral.}

\begin{tabular}{|c|c|c|c|c|}
\hline Strongly Agree & Agree & Neutral & Disagree & Strongly Disagree \\
\hline 1 & 2 & 3 & 4 & 5 \\
\hline
\end{tabular}

STATEMENT

\section{A. NATURE OF SCIENCE}

Scientific knowledge is tentative and fallible in nature.

Scientific discoveries occur as a result of a series of investigations, each one building on earlier one like laying bricks on the wall.

Scientific discoveries do not occur as a result of a logical series of investigations. There is an element of trial and error and often result of a wide variety of studies related to each other in unpredictable ways.

Scientists are creative and often resort to imagination and speculation.

Different competent scientists can interpret the same experimental data in more than one way.

Scientific ideas develop from hypothesis to theories however scientific theories don't necessarily become scientific law even with additional pieces of evidences.

Scientific progress is characterized by competition among rival theories.

Assumptions play an important role in developing new theories or laws, scientists make certain assumptions about nature (for example, matter is made up of atoms). These assumptions form the part of background knowledge.

Scientific ideas are affected by their social and historical culture.

- Scientific models come close to being replica of reality, but they are not the exact reality. This is how scientist builds the model to describe their version of representation of reality of external world.

\section{B. SCIENTIFIC METHODS AND PROCEDURES}

No observations happen independent of supporting framework. All scientific observations are always theory-laden.

Science is essentially characterised by the methods and processes rather than the content of the discipline.

- A scientist's individuality influences the content of a theory because different scientists conduct research differently (for example, probe deeper or ask slightly different questions). Therefore, they will obtain different results. These results then influence the content of a theory.

O. Scientific knowledge relies heavily but not entirely on observations, O experimental evidences, rational arguments and scepticism.

Considering what scientists actually do, there is really is no one such fixed वै thing as "the scientific method". So, there is no one universal method of

$\begin{array}{lllll}1 & 2 & 3 & 4 & 5\end{array}$

1

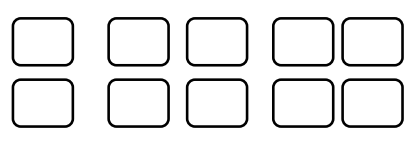

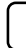
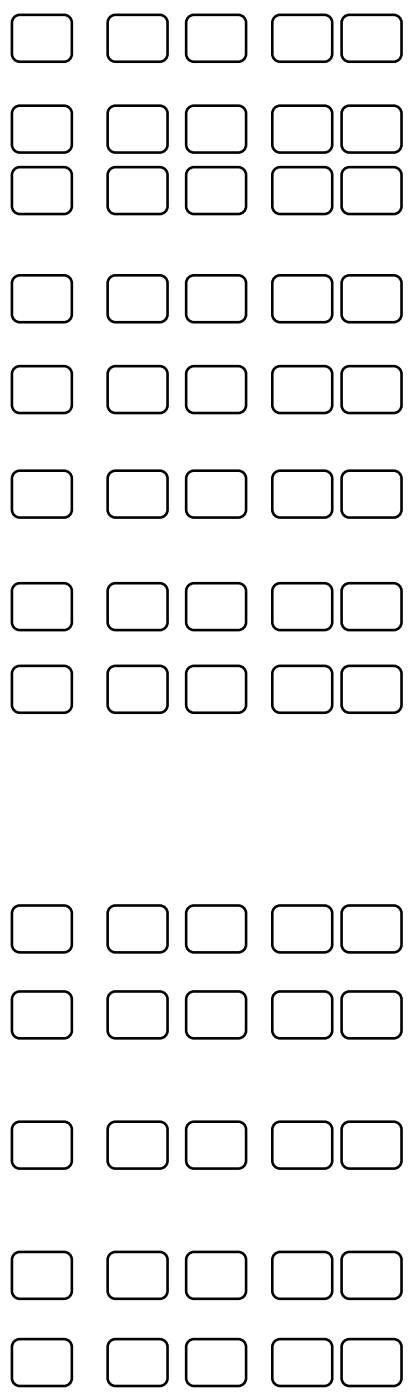
doing science.

With the same background knowledge, two scientists can develop the same theory independently of each other because a theory's content may be influenced by what a scientist wants to believe. Bias does has an influence.

The systematic reasoning taught in science classes for example, hypothesizing, gathering data, logical empiricism are directly useful in my daily life and help to understand a wide variety of physical events (for example, thunder, photosynthesis, rainbow, origin of universe).

Ideas and facts I learn from science classes do not help me to solve practical problems; but it does help me getting good marks in examination.

Scientists are particularly more objective. They display the characteristics of science, not only in their research work, but also in their home and social life as well.

.

Scientific methods do work well in controlled situations but it is not worth applicable in real life situations.

\section{SCIENCE RELATED BEHAVIOURS AND PRACTICES}

'Doing science' always excite me and I put it on top of my agenda.

.I think that learning science is important because I can use it in my daily life.

-I always prefer to scientific explanations rather than conventional explanations available in society like mythical, religious, spiritual, social explanations.

- Science classes have boosted my confidence to become better decisionmaker, citizen and consumer (for example, taking a decision regarding a product, advertisement, or taking initiatives over social issues).

- Science classes have taught me the way of conducting systematic investigation to solving the practical problems in and outside the classroom activities.

.What I learn from science classes like Biology, chemistry and physics are not practical to me. They emphasize theoretical and technical details that have little to do with my day-to-day world. My problems are solved by past experience or by knowledge unrelated to science and technology.

- When science activities are too difficult, I give up easily and do only the easy parts.

.I understand that there is clear cut boundary between science and pseudoscience and can clearly distinguish between the two in real-life situations.

.I often use the scientific knowledge to substantiate my points in my personal and public life.

Scientific arguments consist of explaining the causes and effect analysis in logical, structured and open manner.

\section{SCIENTIFIC DISPOSITION AND PREFERENCES}

I agree with the proposition that to be a person of science invokes following and internalising the core ideas of science like believing in systematic observation and cross-checking the facts, and evidence based formulation. - Scientists too are human being. What they believe in deeply is bound to affect their work like what topics they choose to work and how they work. All these reflect in the outcome of any processes of science.

. Since scientific knowledge is the product of professional criterion, scientist's personal values like religious values don't influence, interfere, and hinder the scientific work.

.Adoption of Scientific worldview quashes the arguments posed by religious arguments like the ideas of Divine Intervention, presence of Benevolent
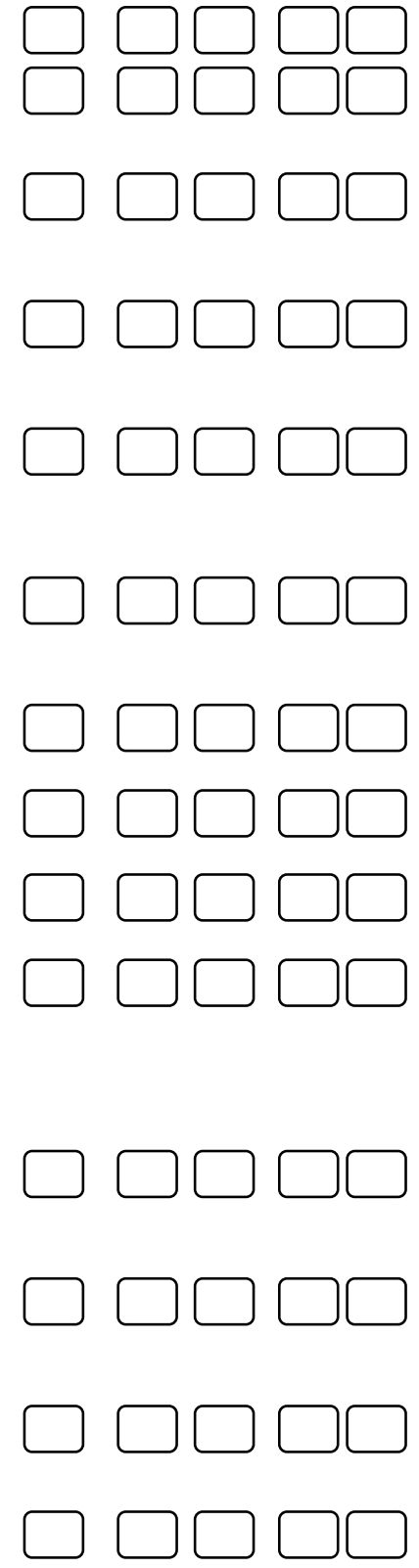
Master, or Intelligent Design etc. Science stops us to believing in any short of miracles, magic power or supernatural power.

- A scientific temper is what you needed most out of science learning to go on making their own decisions.

- My idea of science is based on practicing scientific methods of doing things in life rather than mere memorizing the scientific facts and concepts from science books.

Whenever I confront the socially complex issues, I usually first try to solve it using scientific explanations.

.Science has its own limitations and whenever I am not satisfied by scientific explanations I prefer to go back to the prevailing theories in society.

. The most valuable part of a science education is what remains with learner: adopting the scientific temper of mind. curiosity.

Science demands developing debunking attitude and voyeuristic

\section{E. SCIENCE RECOGNITION}

To be known as a 'person of science' is a matter of great pride for me.

-A person of science usually prefers to understand the issues from many perspectives.

.Science allows a person to develop an understanding that at times defies the social and conventional views.

.Science demands adoption of liberal values like multiculturalism, tolerance, and diversity. It negates any social prejudices based on race, caste, and gender.

- Science and democracy is based on the same mutual principle like respecting the value of others, open-mindedness, transparency, and objectivity.

.Science is absolute unlike social values and preferences, and culture.

-Standing with/for science means going beyond the 'apparent view' of the society and find out the deeper meanings, causes and reasons of the phenomenon.

. Science is the panacea to all social ills.

. Science is particularly a solitary pursuit and personal vocation rather than social.

.Commitment to science demands brevity, honesty, and flexibility. The best and competent scientists are always full of such personal characteristics.
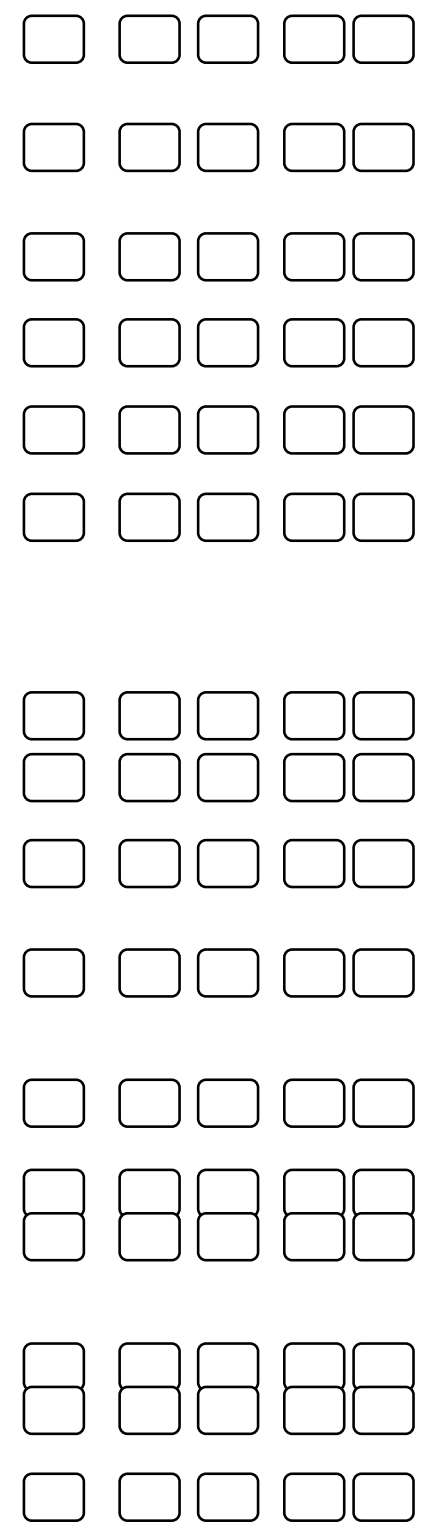